\title{
PENGARUH ASPEK PSIKOLOGIS TERHADAP HASIL BELAJAR MAHASISWA OLAHRAGA
}

\author{
Kurdi dan MFP. Putra \\ Program Studi Ilmu Kelahragaan \\ Fakultas Ilmu Keolahragaan, Universitas Cenderawasih \\ e-mail: kurdimr18@gmail.com
}

\begin{abstract}
Abstrak: Penelitian ini memiliki tujuan untuk mengetahui (1) apakah ada pengaruh pemberian reinforcement terhadap hasil belajar lompat tinggi gaya flop pada mahasiswa olahraga; (2) apakah ada pengaruh pemberian mental imagery terhadap hasil belajar lompat tinggi gaya flop pada mahasiswa olahraga; (3) apakah ada perbedaan hasil belajar lompat tinggi gaya flop antara mahasiswa yang diberikan reinforcement dengan yang diberikan mental imagery. Jenis Penelitian yang digunakan adalah eksperimen semu yang terdiri dari 2 kelompok. Sampel dalam penelitian adalah mahasiswa olahraga semester I Prodi S1 Ikor FIK UNCEN. Alat pengumpul data yang digunakan adalah tes, yaitu tes kemampuan melakukan lompat tinggi gaya flop. Untuk menguji hipotesis penelitian akan digunakan uji beda mean sampel sejenis dan sampel berbeda. Hasil penelitian menemukan (1) ada pengaruh pemberian reinforcement terhadap hasil belajar lompat tinggi gaya flop pada mahasiswa olahraga; (2) ada pengaruh pemberian mental imagery terhadap hasil belajar lompat tinggi gaya flop pada mahasiswa olahraga; (3) tidak ada perbedaan hasil belajar lompat tinggi gaya flop antara mahasiswa yang diberikan reinforcement dengan yang diberikan mental imagery.
\end{abstract}

Kata kunci: reinforcement, mental imagery, gaya flop

\section{PENDAHULUAN}

Proses pengembangan ilmu dari tahap mengambil alih ilmu yang telah dikembangkan di luar negeri hingga mencapai tahap mandiri, memerlukan beberapa syarat. Selain tumbuh sikap ilmiah terutama di kalangan anggota masyarakat akademis, juga terdapat peningkatan keterampilan untuk menerapkan metode ilmiah, kemampuan menilai, dan mengkomunikasi penemuan ilmiah itu sendiri. Ketiga tuntutan itu sekaligus menunjukkan karakteristik ilmu itu sendiri yang bersifat multidimensi. Ia dapat dipahami dari sudut proses dan dapat pula dari sudut produk.

Masa "pendekatan ilmiah" dalam latihan olahraga mulai pada tahun 1940. Peningkatan terjadi hingga tahun 1960 terutama dalam penyempurnaan metode

latihan. Kecenderungan ini terus berkembang, terutama di negara maju. Produk penelitian memegang peranan penting yang membangkitkan masalah baru terutama tentang pnerapan iptek dalam dalam pembinaan olahraga ditinjau aspek moral.

Dalam kehidupan modern manusia tidak dapat dipisahkan dari olahraga, baik sebagai arena adu prestasi maupun sebagai kebutuhan untuk menjaga kondisi tubuh agar tetap sehat. Olahraga mempunyai peranan yang penting dalam kehidupan manusia. Melalui olahraga dapat dibentuk manusia yang sehat jasmani, rohani serta mempunyai kepribadian, disiplin, sportifitas yang tinggi sehingga pada 
akhirnya akan terbentuk manusia yang berkualitas. Dengan adanya kecendrungan prestasi yang meningkat, maka untuk berpartisipasi dan bersaing antar atlet dalam kegiatan olahraga prestasi harus dikembangkan kualitas fisik, teknik, psikologi dan sosial yang dituntut oleh cabang olahraga tertentu. Oleh karena itu, melalui pengembangan dan pembinaan di masyarakat, olahraga wajib diajarkan di berbagai jenjang pendidikan dari sekolah tingkat dasar sampai pada tingkat perguruan tinggi.

Tidak bisa dibantah lagi bahwa atletik merupakan "ibu" dari semua cabang olahraga, karena di dalamnya terkandung unsur-unsur gerak dasar yang dibutuhkan oleh semua cabang olahraga, seperti gerakan jalan, lari, lompat dan lompat. Dilihat dari taksonomi gerak umum, atletik secara lengkap diwakili oleh gerak-gerak dasar yang membangun pola gerak yang lengkap, dari mulai gerak lokomotor, non-lokomotor sekaligus gerak manipulatif. Jika atletik ditinjau dari jenis keterampilannya dapat dimasukkan ke dalam keterampilan diskrit, serial, dan kontinyu. Serta jika ditinjau dari pola lingkungan dimana atletik dilakukan, maka atletik cenderung masuk pada klasifikasi keterampilan tertutup (close skill). Dari struktur pola gerak lokomotor, atletik dapat meningkatkan aspek kekuatan, kecepatan, daya tahan, daya ledak, fleksibilitas dan aspek lainnya. Dihubungkan dengan pola gerak non-lokomotor, atletik mampu mengembangkan aspek kelentukan serta keseimbangan. Dari pola gerak manipulatif, anak-anak bisa diajarkan berbagai macam kegiatan yang bersifat positif seperti : melompat, melempar, melewati rintangan, memanjat dan aspek koordinasi gerak, termasuk rasa kinetik.

Dengan berlatih secara sistematis dan melalui pengulangan-pengulangan yang tetap, maka mekanisme persyaratan faaliah kita akan menjadi bertambah baik. Gerakan-gerakan yang semula sukar dilakukan, lama kelamaan akan merupakan gerakan-gerakan otomatis dan reflektif. Hanya melalui rangsangan maksimal atau hampir maksimal, dan latihan yang setiap hari bertambah berat, perubahan-perubahan dapat dicapai. Prinsip ini biasanya disebut prinsip beban lebih.

Kebanyakan atlet meluangkan waktu yang begitu panjang dalam latihan fisik guna dapat mendapatkan keunggulan dalam kompetisi. Tetapi, mereka sering lupa bahwa dalam kompetisi olahraga, mereka bukan sekedar kemampuan fisik tetapi juga kemampuan mental. Jika ada salah satu aspek yang terabaikan, tujuan yang hendak dicapai melalui latihan akan gagal terwujud, memang, latihan fisik mutlak diperlukan untuk mengasah kemampuan dan keterampilan. Namun, perlu diperhatikan pula, dalam persiapan optimal mengahadapi kompetisi, disamping mengasah keterampilan fisik sebaik mungkin demi kekuatan dan stamina, seorang atlet harus juga mempersiapkan diri secara mental.

Ketika pertandingan sedang berlangsung, adakalanya kondisi psikis memainkan peran lebih penting daripada teknik permainan, sehingga banyak atlet dan pelatih yang mengatakan "dalam olahraga, 90-95\% adalah urusan Mental".

Kesadaran ini mendorong para praktisi olahraga mencari kiat-kiat untuk mempersiapkan atlet secara fisik dan Mental guna menghadapi pertandingan. Di perguruan tinggi peran dosen masih sangat diperlukan dalam upaya menjadikan pembelajaran sebagai sarana pembentukan gerak. Untuk itu dosen perlu memilih cara dan menggunakan metode pembelajaran yang dapat meningkatkan kualitas pembelajaran. 
Secara umum, pemberian materi perkuliahan praktek yang dilakukan staf pengajar di perguruan tinggi tenaga pendidik atau guru pendidikan jasmani olahraga dan kesehatan (Penjasorkes) masih berorientasi produk, belum berorientasi proses. Agar mahasiswa dapat memperoleh hasil belajar yang baik dan efisien, maka dosen perlu melakukan pendekatan-pendekatan yang dapat meningkatkan semangat belajar mahasiswa dalam perkuliahan.

Seperti yag diketahui bahwa dalam semester ganjil tahun akademik 2016/2017 mahasiswa memprogram mata kuliah atletik I. Atletik adalah gabungan dari beberapa jenis olahraga yang secara garis besar dapat dikelompokkan menjadi lari, lempar, dan lompat. Kata ini berasal dari bahasa Yunani "athlon" yang berarti "kontes". Atletik merupakan cabang olahraga yang diperlombakan pada olimpiade pertama pada $776 \mathrm{SM}$. Induk organisasi untuk olahraga atletik di Indonesia adalah PASI (Persatuan Atletik Seluruh Indonesia) (IAAF, 2010). Atletik yang berisi dengan gerak-gerak dasar jalan, lari, lompat dan lompat, sangat cocok untuk membantu para mahasiswa dalam upaya meningkatkan kemampuan geraknya. Dan diantara nomor-nomor tersebut peneliti tertarik mengkaji pada nomor lompat, karena nomor lompat termasuk ke dalam jenis keterampilam asikliss (Acyclic motion).

Nomor lompat yang coba diteliti adalah lompat tinggi dengan gaya flop sebagai kajian penelitian karena faktor kematangan keahlian yang dimiliki. Selain itu pembelajaran akan berlangsung baik, karena materi lompat tinggi mempunyai ekspektasi pembelajaran yang cukup menantang untuk dilaksanakan dan membutuhkan media yang relatif sederhana. Sehingga mempermudah pembelajaran lompat tinggi. Mulai dari modifikasi alat, karakteristik peserta didik, jumlah peralatan yang ada, dan luas lahan yang sangat menunjang.

Lompat Tinggi adalah salah satu keterampilan untuk melewati mistar yang berada di kedua tiangnya. Ketinggian lompatan yang dicapai oleh seorang pelompat tergantung dari kemampuan dan persiapan bertanding dari masing-masing atlet. Menurut Bahagia lompat tinggi adalah termasuk ke dalam lompatan vertikal, karena si pelompat berusaha memindahkan titik berat badan setinggi-tinginya dalam upaya melampaui suatu ketinggian (mistar lompatan).

Jatuhnya tubuh dari ketinggian dan rotasi ke belakang dalam lompat tinggi gaya flop seringkali menyebabkan pelompat mendarat dengan bahu mereka ke belakang. Salah satu faktor yang paling penting dalam lompat tinggi gaya flop yang sukses adalah lengkungan punggung yang eksterm saat melewati palang. Tingkat fleksibilitas yang tinggi ini dikembangkan secara perlahan dan sistematis dalam waktu yang relatif panjang.

Kemudian, variabel bebas aspek psikologis yang akan dijadikan sebagai perlakuan adalah reinforcement dan mental imagery. Paul Chance dalam Khanifah mengatakan "Reinforcement is the procedurre of increasing the likehood of a behavior by following it with some positive consequence". Menurut Khanifah reinforcement merupakan konsekuensi yang memperkuat tingkah laku.

Dikatakan pula bahwa tingkah laku yang diikuti dengan Reinforcement akan diulang diwaktu yang akan datang. Suatu peristiwa yang memperkuat tingkah laku itu bisa menyenangkan atau tidak menyenangkan. Penguatan juga dapat disebut dengan "Reinforcement yang berarti respon positif terhadap suatu tingkah laku tertentu dari siswa 
yang memungkinkan tingkah laku tersebut timbul kembali".

Penguatan adalah unsur penting yang mempengaruhi perbuatan belajar. Bentuk-bentuk penguatan dalam belajar adalah pujian dan hadiah. Seorang ahli terkenal Thorndike dalam eksperimenya atau hukum yang diberi nama hukum akibat (law of effect), menyatakan bahwa respon yang dihargai cenderung diulang pada situasi tertentu, sedangkan respon yang tidak diberikan penghargaan cenderung untuk tidak diulang. Dengan adanya hukum akibat ini berarti pemberian penghargaan pada seorang siswa dalam belajar sangat penting dalam keberhasilan belajarnya.

Dari pengertian di atas kiranya dapat dikatakan bahwa Reinforcement merupakan dorongan atau motivasi ekstrinsik yang sering digunakan oleh guru untuk merangsang minat belajar siswa. Jadi jelasnya bahwa Reinforcement identik dengan motivasi ekstrinsik. Penghargaan sebagai penguat terjadinya belajar (reinforcer) dapat diberikan sesudah terjadinya suatu respon. Setelah mengerjakan suatu soal dengan tepat, misalnya guru memberikan penghargaan kepada siswa dengan jalan memberikan kata-kata pujian.

Pemberian penguatan apabila dilakukan dengan cara dan prinsip yang tepat maka akan mengefektifkan pencapaian tujuan penggunaannya. Adapun tujuan penggunaan penguatan menurut Marno adalah

\section{Meningkatkan perhatian} mahasiswa dalam proses belajar,

2. Membangkitkan, memelihara, dan meningkatkan motivasi belajar mahasiswa,

3. Mengarahkan pengembangan berpikir siswa ke arah berpikir divergen,

4. Mengatur dan mengembangkan diri anak sendiri dalam proses belajar,
5. Mengendalikan serta memodifikasi tingkah laku mahasiswa yang kurang positif serta mendorong munculnya tingkah laku yang produktif

Imagery adalah proses penggunaan imajinasi untuk menciptakan citra-citra yang jelas dan hidup dalam pikiran kita. Melakukan Mental Imagery berarti membayangkan diri sendiri berada dalam linkungan tertentu atau melakukan kegiatan tertentu.

Dalam melakukan Mental Imagery, kita membayangkan diri kita menikmati kegiatan olahraga dan merasa puas dengan kinerja kita. Kita berupaya sepenuhnya terbuka kepada citra-citra yang terbentuk dalam pikiran kita, sekaligus dengan melibatkan semua pacaindera kita. Singkatnya, dalam imajinasi kita, kita membayangkan diri kita melihat, mendengar, menyentuh, merasa dan bertindak persis seperti yang akan kita alami dalam dunia nyata. Citracitra yang terbentuk dalam proses Mental Imagery tersebut dalam melatih jalur-jalur Mental yang penting dalam pikiran kita.

Hal ini senada dengan Djiwandono yang menyatakan bahwa Imagery adalah suatu proses dimana seseorang dapat menciptakan, memodifikasi, atau memperkuat jalurjalur penting untuk koordinasi ototototnya melalui latihan dalam pikiran. Jadi, kekuatan yang mengendalikan Imagery adalah imajinasi. Para taraf yang paling dasar, Imagery dapat digunakan untuk melatih "pusat pengendalian tubuh" ketika tidak ada metode latihan lain. Efektifitas penggunaan Imagery paling kecil adalah jika hanya digunakan sebagai pengganti latihan sesungguhnya.

Bahkan pada penggunaan tingkat rendah, latihan Imagery bermanfaat ketika; 
1. Atlet mengalami cidera dan tidak dapat berlatih dengan cara lain;

2. Tidak tersedia perlengkapan yang tepat, atau tidak mungkin melakukan latihan fisik karena beberapa alasan lain;

3. Dibutuhkan latihan cepat.

Sedangakn pada taraf yang lebih tinggi, Imagery dapat digunakan antara lain untuk

1. Meningkatkan rasa percaya diri;

2. Mempersiapkan Mental untuk hal-hal yang tak terduka dalam latihan;

3. Mengasah keterampilan psikologis tertentu yang amat berguna bagi olahraga;

4. Melatih dan meningkatkan teknik-teknik berolahraga;

5. Memusatkan fikiran sebelum melaksanakan kecakapan dalam sebuah pertandingan.

Hubungan timbal balik antara tubuh dan jiwa menjadi dasar bagi kerja visual Imagery: ketika seseorang atlet membayangkan dirinya sedang bertanding bulutangkis dengan tepat dan sempurna, maka sesungguhnya secara fisiologis ia telah menciptakan pola-pola neural di otaknya, seolah-olah secara fisik dia telah melakukan tindakan itu. Pola ini sama dengan jejak-jejak kecil yang diguratkan di sel-sel otak yang menjadikan sang atlet mampu meraih prestasi fisik hanya dengan secara Mental melatih gerakan-gerakan itu. Mental Imagery berfungsi melatih pikiran dan menciptakan pola-pola neural dalam otak kita untuk melatih otot-otot melakukan secara tepat apa yang kita inginkan.

Seperti keterampilan yang lain, Imagery perlu dikembangkan dan dilatih secara berkesinambungan agar menjadi aktif. Mental Imagery mengandung empat unsur sebagai berikut:
1. Relaksasi: dengan tubuh dan fikiran yang rileks, anda menjadi sungguhsungguh terlibat dalam latihan relaksasi;

2. Realisme: jika seorang atlet mampu menciptakan citra yang begitu nyata, maka itu berarti ia telah menjalankan keterampilan itu dengan sebenar-benarnya.

Untuk menciptakan citra yang sangat nyata seorang atlet harus memadukan:

a) Kejelasan, yaitu membuat citra sehidup-hidupnya sehingga tampak berwarna-warni;

b) Gambaran yang hidup (vivid), yaitu sedapat mungkin menggabungkan beberapa penginderaan kedalam citra-citra sehingga tampak jelas dan senyata keadaan dalam kehidupan yang sesungguhnya;

c) Emosi, yaitu mengupayakan untuk melibatkan perasaanperasaan kedalam citra yang terbentuk, menyadarkan kembali ingatan secara ajeg dengan menekankan pada kesadaran penginderaan tertentu seperti bau-bauan dan angin selama berlatih;

d) Pengendalian, yaitu mengurai citra itu kedalam unsur-unsur kecil yang menyusunnya lalu menggambarkan unsur-unsur tersebut;

e) Hasil positif, kedalam citranya.

3. Keteraturan: agar efektif sebaiknya atlet mencurahkan 3 s/d 5 menit untuk berlatih pencitraan. Diluar latihan, atlet juga disarankan untuk meluangkan waktu 10 s/d 15 menit setiap hari untuk melakukan pencitraan,

4. Pengukuhan: penulis naskah pencitraan akan membantu atlet 
merencanakan dan menetapkan waktu untuk berlatih pencitraan.

Berikut ini adalah pokok-pokok pikiran yang dapat membantu penggunaan Imagery secara efektif

1. Imagery harus tampak jelas dan tegas dalam pikiran Citra (image) yang kuat dan hidup akan lebih efektif dan "nyata" daripada citra yang lemah ketika ia diguratkan pada jalur-jalur syaraf yang tepat dalam otak. Citracitra dapat dibuat lebih nyata dengan cara:

a) Memanfaatkan semua indera dalam pencitraan. Sentuhan, suara, bebauan, dan posisi tubuh seharusnya dipadukan dengan imajinasi visual untuk menghasilkan citra yang benarbenar nyata;

b) Mengerti detail-detail sensasi seperti perasaan ketika menggenggam raket, tekstur pakaian, aroma keringat, merasakan mengalihnya sebuah pukulan karate, gemuruh suara penonton, atau ukuran dan bentuk sebuah stadion tempat bertanding. Semua itu dapat diamati secara rinci dalam kenyataan, dapat dibayangkan dalam citra imajinasi secara lebih "hidup":

c) Membayangkan diri kita "dari dalam": membayangkan diri kita bergerak, merasakan tubuh kita, merasakan segala sesuatu yang bergerak di sekeliling kita, sehingga citra-citra imajinasi menjadi lebih terkait satu dengan yang lain, tampak realistis, dan kita menjadi lebih terlibat.

2. Mulailah dengan lembut dan gunakan Imagery secara sistematis seperti teknik-teknik lain dalam psikologi olahraga, abaiknya kita mulai menggunakan Imagery dengan lembut sehingga kecakapan dasar dalam Imagery dapat sepenuhnya dipelajari dalam lingkungan dengan tingkat stres rendah

Dari uraian di atas, maka peneliti merasa perlu untuk melakukan penelitian dengan pemberian reinforcement dan mental imagery pada pembelajaran lompat tinggi gaya flop sebagai salah satu alternatif untuk meningkatkan hasil belajar mahasiswa pada pembelajaran atletik. Dengan begitu penelitian ini bertujuan untuk mengetahui (1) Apakah ada pengaruh pemberian reinforcement terhadap hasil belajar lompat tinggi gaya flop pada mahasiswa olahraga; (2) Apakah ada pengaruh pemberian mental imagery terhadap hasil belajar lompat tinggi gaya flop pada mahasiswa olahraga; (3) Apakah ada perbedaan hasil belajar lompat tinggi gaya flop antara mahasiswa yang diberikan penguatan dengan yang diberikan mental imagery.

\section{METODE}

Jenis penelitian yang digunakan untuk menguji pengaruh aspek psikologis (pemberian reinforcement dan mental imagery) terhadap hasil belajar lompat tinggi gaya flop pada mata kuliah atletik I adalah kuasi eksperimen. Dari pendapat Putra dan Guntoro dapat disimpulkan bahwa penelitian kuasi eksperimenberupaya memanipulasi satu atau lebih variabel bebas secara sistematis dan logis, mengamati pengaruhnya terhadap variabel-variabel tergantung dan berupaya memperkecil pengaruh variabel yang lain. Sedangkan desain yang digunakan dalam studi ini adalah nonequivalent control group design.

$$
\begin{aligned}
& \mathrm{O}_{1} \mathrm{X}_{1} \mathrm{O}_{2} \\
& \mathrm{O}_{3} \mathrm{X}_{2} \mathrm{O}_{4}
\end{aligned}
$$

\section{Gambar 1. Desain penelitian}


Terdapat tiga variabel dalam penelitian tersebut, yaitu reinforcement dan mental imagery sebagai variable bebas serta hasil belajar lompat tinggi gaya flop sebagai variable terikat.

Populasi dalam penelitian ini adalah seluruh mahasiswa semester Iangkatan 2016 Prodi S1 Ikor FIK UNCEN yang sedang menempuh mata kuliah Atletik I, yaitu berjumlah 81 mahasiswa. Dalam penelitian ini pengambilan sampel dilakukan dengan teknik radom sampling. Dengan teknik tersebut didapat 40 mahasiswa sebagai kelompok yang menerima reinforcement dan 41 yang menerima mental imagery.

Dalam perkembanganya, tidak semua mahasiswa aktif kuliah dan mengikuti treatment yang diberikan. Hal ini lazim disebut dengan mortality. Oleh karena itu data yang akan dianalisis hanya data mahasiswa yang mengikuti tes awal, treatment dan tes akhir. Apabila mahasiswa tersebut tidak mengikuti rangkaian kegiatan yang sudah diprogram maka datanya tidak akan dimasukan dan dianalisis lebih lanjut. Berdasarkan kriteria tersebut, jumlah sampel dalam kelompok reinforcement menjadi 27 sedangkan kelompok mental imagery berjumlah 25 mahasiswa.

Instrumen penelitian yang digunakan untuk mengambil data variabel terikat adalah tes, yaitu tes kemampuan melakukan lompat tinggi gaya flop. Kemudian alat untuk melakukan tratment pada mahasiswa adalah sebuah program pemberian reinforcement dan mental imagery.

Teknik analisis data dalam penelitian akan mengunakan uji beda mean atau uji t. Untuk mengetahui apakah ada pengaruh pemberian reinforcement dan mental imagery terhadap hasil belajar lompat tinggi gaya flop pada mahasiswa Prodi S1 Ikor Semester I maka akan digunakan uji beda sampel sejenis. Kemudian untuk mengetahui apakah ada perbedaan hasil belajar lompat tinggi gaya flop antara mahasiswa yang diberikan penguatan reinforcement dengan yang diberikan mental imagery akan digunakan uji beda dua sampel. Analisis data di atas akan dilakukan dengan bantuan program komputer, yaitu menggunakan Statistical Package for Social Science for Windows Release 22.0 .

\section{HASIL DAN PEMBAHASAN}

Pada bagian ini akan dipaparkan secara berurutan deskripsi, hasil kelompok reinforcement, hasil keleompok mental imagery dan uji beda.

\section{Deskripsi Hasil Penelitian}

Berdasarkan hasil analisis menggunakan program Statistical Package for Social Science for Windows Release 22.0 (SPSS 22.0)dapat dideskripsikan hasil penelitian seperti pada tabel 1 di bawah.

Tabel 1. Deskripsi Hasil Tes

\begin{tabular}{lllll} 
& \multicolumn{2}{l}{ Reinforcement } & \multicolumn{2}{l}{$\begin{array}{l}\text { Mental } \\
\text { Imagery }\end{array}$} \\
\cline { 2 - 5 } & Pretest & Postte & Pretes & Poste \\
& st & st & st \\
\cline { 2 - 5 } Mean & 101 & 118 & 102 & 114 \\
SD & 10,76 & 13,61 & 9,65 & 11,47 \\
$\sum \mathbf{N}$ & 27 & & 25 & \\
\hline \multicolumn{3}{c}{ Sumber: hasil pengolahan data }
\end{tabular}

Dari tabel 1 didapat nilai rata-rata tes awal lompat tinggi gaya flop pada kelompok reinforcement sebelum diberikan pembelajaran lompat tinggi gaya flop sebesar 101, dengan standart deviasi sebesar 10,76 dan jumlah sampel sebanyak 27 mahasiswa.Kemudian nilai rata-rata tes akhir setelah diberikan pembelajaran lompat tinggi gaya flop dengan menggunakan reinforcement sebesar 118, dengan standart deviasi sebesar 13,65. 
Untuk kelompok mental imagery didapat nilai rata-rata tes awal lompat tinggi gaya flop sebelum diberikan pembelajaran lompat tinggi gaya flop sebesar 102, dengan standart deviasi sebesar 9,65 dan jumlah sampel sebanyak 25 mahasiswa. Kemudian nilai rata-rata tes akhir setelah diberikan pembelajaran lompat tinggi gaya flop dengan menggunakan mental imagery sebesar 114, dengan standart deviasi sebesar 11,47.

Dari hasil uraian di atas dapat diketahui bahwa ada perubahan pada nilai rata-rata antara tes awal dengan tes akhir, baik pada kelompok reinforcement maupun kelompok mental imagery. Namun begitu, untuk mengetahui apakah ada pengaruh yang signifikan atau tidak pengujian harus dilakukan dengan analisis lebih lanjut. Kenapa? Karena hasil analisis deskriptif tidak mampu menyimpulkan apakah ada pengaruh pemberian perlakukan terhadap hasil lompat tinggi gaya flop.

\section{Hasil Kelompok Reinforcement}

Dalam sub bab pembahasan ini akan diarahkan untuk menjawab rumusan masalah pertama yaitu apakah ada pengaruh pemberian reinforcement terhadap hasil belajar lompat tinggi gaya flop pada mahasiswa olahraga. Untuk mengetahui hal tersebut maka uji beda sampel sejenis yang akan digunakan. Analisis data akan dibantu dengan program SPSS Versi 22. Berikut ini adalah hasilnya:

Tabel 2. Hasil Uji Beda Kelompok

\begin{tabular}{lllll} 
& \multicolumn{4}{c}{ Reinforcement } \\
\cline { 2 - 5 } & $\mathbf{N}$ & Mean & SD & P \\
& & & value \\
\hline Pretest & 27 & 101 & 10,76 & 0,0001 \\
Posttes & 27 & 118 & 13,61 & \\
\hline \multicolumn{5}{c}{ Sumber: hasil pengolahan data }
\end{tabular}

Berdasarkan tabel 2 di atas dapat diketahui nilai rata-rata dan standar deviasi baik saat tes awal maupun tes akhir. Untuk mengetahui apakah ada pengaruh pemberian penguatan (reinforcement) terhadap hasil belajar lompat tinggi gaya flop pada mahasiswa olahraga dapat dilihat pada nilai kolom $\mathrm{P}$ value. Dengan nilai $\mathrm{p}$ value sebesar 0,0001 maka itu berarti nilai tersebut lebih kecil dari nilai alpha $(\alpha) 0,05 \%$. Itu artinya, hipotesis kerja yang menyatakan ada pengaruh pemberian reinforcement terhadap hasil belajar lompat tinggi gaya flop pada mahasiswa olaharaga diterima.

Apabila dilihat nilai rata-rata antara tes awal dengan tes akhir maka akan ditemukan perbedaan sebesar 17 . Itu artinya terdapat peningkatan hasil lompatan antara sebelum diberikan perlakuan reinforcement dengan sesudah diberikan perlakuan reinforcement.

Dengan kata lain pemberian reinforcement efektif dalam meningkatkan hasil belajar lompat tinggi gaya flop pada mahasiswa olahraga. Hasil tersebut sebenarnya tidak begitu mengherankan karena selama proses penelitian tampak bahwa mahasiswa lebih semangat dan percaya diri dalam melakukan lompatan ketika mereka diberikan reinforcement.

\section{Hasil Kelompok Mental Imagery}

Dalam sub bab pembahasan ini akan diarahkan untuk menjawab rumusan masalah kedua yaitu apakah ada pengaruh pemberian mental imagery terhadap hasil belajar lompat tinggi gaya flop pada mahasiswa olahraga. Untuk mengetahui hal tersebut maka uji beda sampel sejenis yang akan digunakan. Analisis data akan dibantu dengan program SPSS Versi 22. Berikut ini adalah hasilnya:

Tabel 3. Hasil Uji Beda Kelompok Mental Imagery

\begin{tabular}{lllll} 
& N & Mean & SD & $\begin{array}{l}\text { P } \\
\text { value }\end{array}$ \\
\cline { 2 - 5 } Pretest & 25 & 102 & 9,66 & 0,0001 \\
Posttes & 25 & 114 & 11,47 & \\
\hline \multicolumn{4}{c}{ Sumber: hasil pengolahan data }
\end{tabular}


Berdasarkan tabel 3 di atas dapat diketahui nilai rata-rata dan standar deviasi, baik saat tes awal maupun tes akhir. Untuk mengetahui apakah ada pengaruh pemberian mental imagery terhadap hasil belajar lompat tinggi gaya flop pada mahasiswa olahraga dapat dilihat pada nilai kolom $\mathrm{P}$ value. Dengan nilai $\mathrm{p}$ value sebesar 0,0001 maka itu berarti nilai tersebut lebih kecil dari nilai alpha $(\alpha) 0,05 \%$. Itu artinya, hipotesis kerja yang menyatakan ada pengaruh pemberian mental imagery terhadap hasil belajar lompat tinggi gaya flop pada mahasiswa olahraga diterima.

Apabila dilihat nilai rata-rata antara tes awal dengan tes akhir maka akan ditemukan perbedaan sebesar 12 . Itu artinya terdapat peningkatan hasil lompatan antara sebelum diberikan perlakuan mental imagery dengan sesudah diberikan perlakuan reinfor mental imagery. Hasil tersebut menunjukkan bahwa mental imagery efektif dalam meningkatkan hasil belajar lompat tinggi gaya flop pada mahasiswa olahraga.

\section{Uji Perbedaan Kedua Kelompok}

Dalam sub bab pembahasan ini akan diarahkan untuk menjawab rumusan masalah ketiga, yaitu apakah ada perbedaan hasil belajar lompat tinggi gaya flop antara mahasiswa yang diberikan reinforcement dengan yang diberikan mental imagery. Untuk mengetahui hal tersebut maka uji beda sampel berbeda akan digunakan. Analisis data akan dibantu dengan program SPSS Versi 22. Berikut ini adalah hasilnya:

Tabel 4. Hasil Uji Beda Antar Kelompok

\begin{tabular}{lllll}
\hline Kelompok & N & Mean & SD & $\begin{array}{l}\text { P } \\
\text { value }\end{array}$ \\
\hline Reinforcement & 27 & 118 & 13,61 & 0,285 \\
Mental Imagery & 25 & 114 & 11,47 & 0 \\
\hline \multicolumn{5}{c}{ Sumber: hasil pengolahan data }
\end{tabular}

Berdasarkan tabel 4 di atas dapat diketahui nilai rata-rata dan standar deviasi baik pada kelompok reinforcement maupun kelompok mental imagery. Untuk mengetahui apakah ada perbedaan hasil belajar lompat tinggi gaya flop antara mahasiswa yang diberikan penguatan (reinforcement) dengan yang diberikan mental imagery kita dapat melihat pada nilai di kolom $P$ value. Dengan nilai $\mathrm{p}$ value sebesar 0,285 maka itu berarti nilai tersebut lebih kebesar dari nilai alpha $(\alpha) 0,05 \%$. Itu artinya, hipotesis kerja yang menyatakan ada perbedaan hasil belajar lompat tinggi gaya flop antara mahasiswa yang diberikan reinforcement dengan yang diberikan mental imagery ditolak.

Apabila dilihat nilai rata-rata antara kelompok reinforcement dengan kelompok mental imagery maka akan ditemukan perbedaan sebesar 4. Dengan kata lain selisih nilai rata-rata antara kedua kelompok tersebut tidak begitu tinggi.

Meskipun demikian bila melihat nilai selisih rata-rata tes awal dengan tes akhir maka akan didapat sedikit perbedaan. Pada kelompok reinforcement didapat selisih 17 sedangkan pada kelompok mental imagery sebesar 12. Itu artinya, pemberian reinforcement sedikit lebih efektif dalam meningkatkan hasil belajar lompat tinggi gaya flop pada mahasiswa olahraga.

\section{PENUTUP}

Kesimpulan. Berdasarkan hasil dan pembahsan di atas dapat disimpulkan

1. Ada pengaruh pemberian reinforcement terhadap hasil belajar lompat tinggi gaya flop pada mahasiswa olahraga.

2. Ada pengaruh pemberian mental imagery terhadap hasil belajar lompat tinggi gaya flop pada mahasiswa olahraga. 
3. Tidak ada perbedaan hasil belajar lompat tinggi gaya flop antara mahasiswa yang diberikan reinforcement dengan yang diberikan mental imagery.

Saran. Terdapat tiga saran yang diberikan terkait dengan hasil temuan penelitian tersebut, yaitu:

1. Dosen perlu lebih sering memberikan reinforcement pada mahasiswa dalam perkualiahan agar hasil belajar mahasiswa meningkat.

2. Mental imagery dapat dijadikan sebagai alteratif strategi untuk meningkatkan hasil belajar belajar mahasiswa terutama dalam mata kuliah praktik.

3. Untuk penelitian berikutnya hendaknya dilakukan dengan jumlah sampel yang lebih besar dan berbeda program studi.

\section{DAFTAR PUSTAKA}

Adisasmita, M. Y. Olahraga Pilihan Atletik. Jakarta: Ditjend Dikti Depdikbud, 1992.

Bahagia, Yoyo. Pembelajaran Atletik Implementasi Pembelajaran Nomor Lompat. Jakarta: Ditplb Depdiknas, 2005.

Buchari, Alma. Guru Profesional Menguasai Metode dan Terampil Mengajar. Bandung: Alfabeta, 2008.

Carr, Gerry A. Atletik Untuk Sekolah. Jakarta: PT. Raja Grafindo Persada, 1997.

Djiwandono, SEW. Psikologi Pendidikan. Jakarta : PT Grasindo, 2002.

IAAF. Peraturan Perlombaan Atletik. Jakarta: Staf Sekretariat RDC, 2010.

Jarver, Jess. Belajar dan Berlatih Atletik. Bandung: Pionir Jaya, 2007.

Khanifah. Studi Tentang Hubungan Antara Motivasi Belajar dan
Pemberian Reinforcment Kepada Anak Dengan Prestasi Belajar Siswa Kelas II SMA Muhammadiyah VI Yogyakarta Tahun 1991. Skripsi. tidak diterbitkan. Yogyakarta: FIP IKIP Yogyakarta, 1991.

Lutan, Rusli, dkk. Seri Bahan Kuliah ITB (Manusia dan Olahraga). Bandung: ITB dan FPOK IKIP Bandung, 2001.

Marno, dkk. Strategi dan Pengajaran. Jogjakarta: Ar-Ruzz Media, 2008

Nurhasan, dkk. Petunjuk Praktis Pendidikan Jasmani. Surabaya: Unesa University Press, 2005.

Sugarman, Karlene. Why Mental Training? (Online), (http://www.com/sports/index.ht ml, diakses 24 Januari 2009.

Widya, M. D. A. Belajar Berlatih Gerak-gerak Dasar Atletik Dalam Bermain. Jakarta: PT. Raja Grafndo, 2004.

Widya, M. D. A. Lompat Tinggi (Online),http://id.wikipedia.org/w iki/Lompat tinggi, diakses 29 juni 2010, 2010. 